\title{
HUBUNGAN PENGETAHUAN DAN SIKAP IBU HAMIL DENGAN KEJADIAN MUAL MUNTAH PADA KEHAMILAN TRIMESTER PERTAMA DI POSKESDES AMPALU KOTA PARIAMAN BIDAN HELFIATI, Amd.Keb.
}

\author{
Relationship Between Knowledge And Attitudes Of Pregnant Women And The \\ Occurrence Of Vomiting In First Trimester Pregnancy In Poskesdes Ampalu Kota \\ Pariaman Bidan Helfiati, Amd. Keb.
}

\section{Rika Armalini I ${ }^{\text {* }}$ \\ Prasetyaningsih $\mathbf{2}^{2}$}

*ISTIKes Piala Sakti I, Kota Pariaman, Sumatera Barat, Indonesia.

2STIKes Piala Sakti 2, Kota Pariaman, Sumatera Barat, Indonesia

*email:

Midwife_rika@yahoo.co.id

\begin{abstract}
Abstrak
Mual muntah pada kehamilan adalah fisiologis yang terjadi pada trimester I, yang dimulai 6 minggu setelah hari petama menstruasi terakhir, dan menghilang 6-12 minggu kemudian. Hasil laporan menunjukkan hampir $50-90 \%$ wanita hamil mengalaminya. Mual muntah apabila tidak diatasi dapat menyebabkan dehidrasi berat sampai terjadi keracunan. Tujuan penelitian ini adalah untuk hubungan pengetahuan dan sikap ibu hamil dengan kejadian mual muntah pada kehamilan trimester pertama di Poskesdes Ampalu Bidan Helfiati, Amd.Keb. Penelitian dilakukan pada bulan Juli 2019. Jenis penelitian ini penelitian survey analitik dengan desain cross sectional. Populasi pada penelitian ini semua ibu hamil yang berkunjung ke polindes Helfiati Amd.Keb sebanyak 40 orang ibu hamil dengan teknik pengambilan sampel secara total sampling. Data di analisis secara univariat dan bivariat secara komputerisasi dengan uji statistik menggunakan SPSS Ver. 17 dengan batas kemaknaan $\alpha=0,05$ dan derajat kepercayaan $95 \%$. Hasil analisa univariat menunjukkan bahwa, 52,5\% ibu mengalami mual muntah, $62,5 \%$ ibu berpengetahuan rendah dan $42,5 \%$ ibu bersikap negatif tentang cara mengatasi mual muntah. terdapat hubungan yang bermakna antara pengetahuan $(p=0,000)$ dan sikap $(p=0,000)$ dengan kejadian mual muntah pada kehamilan trimester pertama di Poskesdes Ampalu Bidan Helfiati, Amd.Keb tahun 2019. Hasil penelitian ini dapat disimpulkan bahwa ada hubungan yang bermakna antara pengetahuan dan sikap dengan kejadian mual muntah. Dengan adanya penelitian ini diharapkan petugas kesehatan menyediakan pelayanan KIE dan meningkatkan penyuluhan pelayanan kesehatan dalam upaya meningkatkan pengetahuan ibu hamil tetang cara mengatasi mual muntah, dan juga diharapkan ibuibu harus lebih aktif mencari informasi tentang keluhan-keluhan fisiologis selama kehamilan khususnya cara mengatasi mual muntah dengan mengikuti kegiatan penyuluhan yang diadakan oleh petugas kesehatan sehingga kedepannya pengetahuan ibu lebih banyak
\end{abstract}

\section{Abstract}

Nausea, vomiting in pregnancy is physiological that occurs in the first trimester, which starts 6 weeks after the first day of the last menstrual period, and disappears 6-12 weeks later. The report shows that almost $50-90 \%$ of pregnant women experience it. Nausea, vomiting if not treated can cause severe dehydration until poisoning occurs. The purpose of this study was to link the knowledge and attitudes of pregnant women with the occurrence of nausea and vomiting in the first trimester of pregnancy in the Poskesdes Ampalu Midwife Helfiati, Amd. Keb. The study was conducted in July 2019. This type of research is analytic survey research with cross sectional design. The population in this study were all pregnant women who visited Helfiati Amd.Keb polindes as many as 40 pregnant women with a total sampling technique. Data were analyzed by univariate and bivariate by computerized statistical tests using SPSS Ver. 17 with a significance level $\alpha=0.05$ and a degree of confidence of $95 \%$. The results of univariate analysis showed that, $52.5 \%$ of mothers experienced nausea, vomiting, $62.5 \%$ low-knowledge mothers and $42.5 \%$ of mothers were negative about how to deal with nausea and vomiting. there is a significant relationship between knowledge $(p=0,000)$ and attitude $(p=0,000)$ with the incidence of nausea and vomiting in the first trimester of pregnancy in the Poskesdes Ampalu Midwife Helfiati, Amd.Keb 2019. The results of this study can be concluded that there is a significant relationship between knowledge and attitude with the occurrence of nausea, vomiting. With this research it is expected that health workers provide IEC services and improve health care counseling in an effort to increase the knowledge of pregnant women about how to cope with nausea, and also expect mothers to be more active in seeking information about physiological complaints during pregnancy, especially how to deal with nausea vomiting by following counseling activities held by health workers so that in the future more knowledge from mothers 
Rika Armalini, Prasetyaningsih. 2020. Relationship Between Knowledge And Attitudes Of Pregnant Women And The Occurrence Of Vomiting In First Trimester Pregnancy In Poskesdes Ampalu Kota Pariaman Bidan Helfiati, Amd. Keb.

\section{PENDAHULUAN}

Mortalitas dan morbiditas pada wanita hamil dan bersalin adalah masalah besar bagi negara-negara berkembang. Di negara miskin sekitar 20-50\% kematian wanita usia subur disebabkan oleh hal yang berkaitan dengan kehamilan. Menurut data statistik yang dikeluarkan WHO (Word Healty Organisasion) sebagai badan PBB (Persatuan Bangsa-bangsa) yang menangani masalah bidang kesehatan, tercatat angka kematian ibu dalam persalinan di dunia mencapai 515.000 jiwa setiap tahun. Keluhan mual muntah ini dikatakan wajar jika dialami pada usia kehamilan 8-12 minggudan semangkin berkurang secara bertahap hingga akhirnya berhenti diusia kehamilan 16 minggu. Mual (nausea) dan muntah (emesis gravidarum) adalah gejala yang sering terjadi pada 60-80\% Primigravida dan 40-60\% Multigravida. Berdasarkan profil kesehatan indonesia 2010 (Depkes, 2010). Perubahan sistem didalam tubuh ibu terjadi dalam proses kehamilan yang semuanya membutuhkan suatu adaptasi, baik fisik maupun psikologis. Dalam proses adaptasi tersebut tidak jarang ibu akan mengalami ketidaknyamanan yang meskipun hal itu adalah fisiologis namun tetap perlu diberikan suatu pencegahan dan perawatan (Janiwarti, 2013). Trimester pertama sering dianggap sebagai periode penyesuaian, dari penyesuaian tersebut ibu akan mengalami ketidaknyamanan yang umum biasanya terjadi yaitu akan merasakan sakit kepala dan pusing, merasa cepat lelah, sering buang air kecil, keputihan, kembung, sesak nafas, kram perut, dan termasuk didalamnya yaitu emesis gravidarum (Rukiah, 20I3). Pada trimester I sering terjadi penurunan nafsu makan akibat nausea (mual) dan atau vomitus (muntah) yang merupakan akibat perubahan saluran cerna dan peningkatan kadar progesteron, estrogen dan human chorionic gonadotropin (hCG) dapat menjadi faktor pencetus mual dan muntah. Peningkatan hormone progesteron menyebabkan otot polos pada sistem gastrointestinal mengalami relaksasi sehingga motilitas lambung menurun dan pengosongan lambung melambat. Refluks esofagus, penurunan motilitas lambung dan penurunan sekresi asam hidroklorid juga berkontribusi terhadap terjadinya mual dan muntah hal ini diperberat dengan adanya penyebab lain berkaitan dengan faktor psikologis, spiritual, lingkungan dan sosiokultural (Hutahaean, Runiari, 2010). Pengetahuan adalah hasil "tahu" dan ini terjadi setelah orang melakukan pengindraan terhadap suatu objek tertentu. Pengindraan terjadi melalui pasca indra manusia yakni indra penglihatan, pendengaran, penciuman, rasa dan raba sebagian besar pengetahuan manusia diperoleh melalui mata dan telinga. Pengetahuan atau kognitif merupakan domain yang sangat penting dalam membentuk tindakan seseorang ( overt behavior) (Notoatmodjo, 20II). Sikap adalah pandanganpandangan atau perasaan yang disertai kecenderungan untuk bertindak sesuai sikap objek. Fakto-faktor yang dapat mempengaruhi sikap adalah pengalaman pribadi, pengaruh orang lain dianggap penting, pengaruh kebudayaan, media massa, lembaga pendidikan dan lembaga agama serta faktor emosi (Wawan dan Dewi, 20II). Penyebab emesis gravidarum belum di ketahui secara pasti, tidak ada bukti bahwa penyakit ini disebabkan oleh faktor toksis, kelainan biokimia, perubahanperubahan anatomik yang terjadi pada otak, jantung, hati dan susunan syaraf di sebabkan oleh kekurangan vitamin serta zat-zat lain akibat kelemahan tubuh karena tidak makan dan minum, beberapa faktor predisposisi dan faktor lain yang telah ditemukan adalah sering terjadinya pada primigravida, masuknya vili khorialis dalam sirkulasi maternal dan perubahan metabolisme akibat hamil serta resistensi yang menurun dan pihak ibu terhadap perubahan ini merupakan faktor organik alergi, faktor psikologik, faktor adaptasi dan hormonal (Rukiyah, 2010). Berdasarkan data yang peneliti dapatkan di Poskesdes Helfiati Amd.Keb tahun 2019 diketahui bahwa kunjungan ibu hamil dari bulan januari sampai mei 2019 adalah 40 orang.

\section{METODOLOGI}


Jenis penelitian kuantitatif dengan desain survey analitik dengan pendekatan cross sectional artinya penelitian ini bertujuan untuk menggambarkan atau menjelaskan bagaimana hubungan pengetahuan dan sikap ibu hamil dengan kejadian mual muntah pada kehamilan trimester pertama di poskesdes ampalu helfiati Amd.keb tahun 2019. Penelitian dilakukan di poskesdes helfiati Amd.keb. Waktu penelitian dilaksanakan pada bulan juli selama 2 minggu 2019. Sampel diambil dengan menggunakan metode total sampling yaitu pengambilan sampel yang mewakili seluruh anggota populasi (Hidayat, 20I I). Kriteria inklusi sampel dalam penelitian ini adalah: I. Ibu hamil yang berkunjung ke 2. Ibu hamil yang kooperatif 3. Berada ditempat saat melakukan penelitian 4. Bisa tulis baca Kriteria Ekslusi: I. Ibu yang tidak hamil berkunjung ke puskesmas pariaman 2. Tidak berada disaat penelitian.

\section{HASIL DAN PEMBAHASAN}

\section{Pengetahuan ibu}

Berdasarkan hasil penelitian dapat diketahui bahwa dari 40 responden,sebagian besar $(62,5 \%)$ responden yaitu 25 orang ibu berpengetahuan rendah dengan kejadian mual muntah pada kehamilan trimester pertama di Poskesdes Ampalu Bidan Helfiati, Amd.Keb tahun 2019. Hasil penelitian ini berbeda dengan penelitian yang dilakukan oleh Siti Zaerotun, dkk (2015) tentang hubungan karakteristik, paritas dan pengetahuan dengan upaya mengatasi mual muntah pada kehamilan trimester I dengan hiperemesis gravidarumdi rumah sakit PKU Muhammadiyah Gubug Kabupaten Grobogan, dari hasil penelitian menunjukkan bahwa sebagian besar pengetahuan responden adalah baik yakni sebanyak 23 orang $(63,9 \%)$. Pengetahuan adalah merupakan hasil "tahu" dan ini terjadi setelah orang melakukan penginderaan terhadap suatu objek tertentu. Penginderaan ini terjadi melalui panca indra manusia. Pengetahuan atau kognitif merupakan domain yang sangat penting bagi terbentuknya tindakan seseorang.
Perilaku yang didasari oleh pengetahuan akan lebih langgeng daripada perilaku yang tidak didasari oleh pengetahuan (Nursalam, 20l4). Pengetahuan atau kongnitif merupakan domain yang sangat penting untuk terbentuknya tindakan seseorang (overt behavior). Pendidikan kesehatan tentang hiperemesis gravidarum yang diberikan kepada klien dan keluarga meliputi penyebab, komplikasi dan manajemen perencanaan, hal tersebut sangat penting karena peningkatan pemahaman akan mempengaruhi keadaan klien dan janinnya. Pemberian informasi yang adekuat dan pelibatan klien dalam pengambilan keputusan yang berkaitan dengan kehamilannya akan memberdayakan dan meningkatkan kerjasama dengan pemberi pelayanan kesehatan (Runiari, 20l0). Berdasarkan hasil penelitian masih banyaknya terdapat responden yang berpengetahuan rendah, menurut analisa peneliti rendahnya pengetahuan responden tergambar dari banyak responden yang tidak mengerti dan memahami tentang penyebab terjadinya mual muntah, cara menangani mual muntah, ibu tidak mengetahui cara menindak lanjuti kalau ibu sering-sering mual dan muntah sehingga ibu terus-terusan mual muntah sehingga mengakibatkan si ibu lelah. Hal ini tidak terlepas dari banyaknya tingkat pendidikan ibu yang rendah, karena pengetahuan sangat erat hubungannya dengan pendidikan, dimana diharapkan bahwa dengan pendidikan yang tinggi maka orang tersebut akan semakin luas pula pengetahuannya. $\mathrm{Hal}$ ini terlihat dari mayoritas responden yang berpengetahuan rendah adalah responden yang berpendidikan kurang, dengan pendidikan yang minim sehingga mereka tidak bisa memahami informasi yang diperoleh sehingga ibu tidak mengetahui tanda dan bahaya pada kehamilan trimester I salah satunya ibu mengalami mual dan muntah.

\section{Sikap ibu}

Berdasarkan hasil penelitian dapat diketahui bahwa dari 40 responden, kurang dari sebagian(42,5\%) responden 
Rika Armalini, Prasetyaningsih. 2020. Relationship Between Knowledge And Attitudes Of Pregnant Women And The Occurrence Of Vomiting In First Trimester Pregnancy In Poskesdes Ampalu Kota Pariaman Bidan Helfiati, Amd. Keb.

yaitu 17 orang ibu bersikap negatif dengan kejadian mual muntah pada kehamilan trimester pertama di Poskesdes Ampalu Bidan Helfiati, Amd.Keb tahun 2019. Hasil penelitian ini beda dengan penelitian yang dilakukan oleh Octaviani, dkk (20I6) tentang hubungan pengetahuan dengan sikap ibu hamil dalam mencegah kejadian hiperemesis gravidarum di Wilayah Kerja Puskesmas Padalarang, berdasarkan hasil penelitian diperoleh hasil bahwa sebagian ibu hamil $(54,8 \%)$ yaitu 57 orang ibu hamil memiliki sikap yang positif dalam mencegah kejadian hiperemesis gravidarum dan sebagian orang ibu hamil $(45,2 \%)$ yaitu 47 orang ibu hamil memiliki sikap yang negatif dalam mencegah kejadian hiperemesis gravidarum. Sikap adalah keadaan mental dan saraf dari kesiapan yang diatur melalui pengalaman yang memberikan pengaruh dinamik atau terarah terhadap respon individu pada semua objek dan situasi yang berkaitan dengannya. Sikap belum merupakan salah satu tindakan atau aktivitas, akan tetapi merupakan predisposisi tindakan suatu perilaku. Sikap itu masih merupakan reaksi tertutup, bukan merupakan reaksi terbuka atau tingkah laku yang terbuka. Sikap merupakan kesiapan untuk bereaksi terhadap objek di lingkungan tertentu sebagai suatu penghayatan terhadap objek (Widayatun, 20I4). Berdasarkan hasil penelitian pada umumnya ibu bersikap negatif tentang cara penanganan mual muntah. Menurut analisa peneliti hal ini disebabkan karena pada penelitian ini hampir sebagian besar (62,5\%) pengetahuan ibu rendah sehingga ibu menganggap mual muntah adalah hal yang biasa saja dalam kehamilan tanpa membutuhkan penanganan khusus. Karena pembentukan sikap seseorang berawal dari pengetahuannya, semakin banyak informasi yang didapat oleh responden tentang masalah- masalah dalam kehamilan khsusnya tentang mual dan muntah maka pengetahuannya akan semakin luas pula, sehingga akan terbentuk sikap yang positif terhadap kejadian mual muntah maka ibu menanggapi dengan serius atau peduli dengan kejadian mual dan muntah dialaminya.

\section{Kejadian mual muntah}

Berdasarkan hasil penelitian dapat diketahui bahwa dari 40 responden,sebagian besar (52,5\%) responden yaitu 2I orang ibu mengalami mual muntahpada kehamilan trimester pertama di Poskesdes Ampalu Bidan Helfiati, Amd. Keb tahun 2019. Hasil penelitian ini berbeda dengan penelitian yang dilakukan oleh Siti Zaerotun, dkk (20I5) tentang hubungan karakteristik, paritas dan pengetahuan dengan upayamengatasi mual muntah pada kehamilan trimester I dengan hiperemesis gravidarumdi rumah sakit PKU Muhammadiyah Gubug Kabupaten Grobogan, berdasarkan hasil penelitian menunjukkan bahwa upaya mengatasi mual muntah ibu sebagian besar adalah baik yakni sebanyak 23 orang $(63,9 \%)$. Mual muntah adalah keluhan mual dan muntah dalam masa kehamilan yang dapat menyebabkan kekurangan cairan, penurunan berat badan, atau gangguan elektrolit, sehingga menganggu aktivitas sehari-hari dan membahayakan janin dalam kandungan. Mual dan muntah berlebihan yang terjadi pada wanita hamil dapat menyebabkan terjadinya ketidak keseimbangan kadar elektrolit, penurunan berat badan (lebih dai $5 \%$ berat badan awal), dehidrasi, ketosis, dan kekurangan nutrisi. $\mathrm{Hal}$ tersebut mulai terjadi pada minggu keempat sampai kesepuluh kehamilan dan selanjutnya akan membaik pada usia kehamilan 20 minggu, namun pada beberapa kasus dapat terus berlanjut smpai pada kehamilan tahap berikutnya (Runiari, 2010). Runiari (2010) menjelaskan beberapa teori penyebab terjadinya mual muntah namun tidak ada satupun yang dapat menjelaskan proses terjadinya secara tepat. Tetapi secara patologi mual muntah disebabkan karena peningkatan Hormone Chorionic Gonodhotropin (HCG) dapat menjadi faktor mual dan muntah. Peningkatan kadarhormon progesteron menyebabkan otot polos pada sistem gastrointensial mengalami relaksasi shinga mortilitas menurun dan lambung menjadi kosong. Menurut analisa peneliti banyaknya ibu-ibu mengalami mual muntah pada penelitian ini tidak terlepas dari rendahnya pengetahuan mereka, sehingga ibu-ibu tidak mengetahui bahaya 
dalam kehamilan salah satunya adalah mual dan muntah, ibu tidak mengetahui penyebab dari mual dan muntah yang dialaminya sehingga ibu tidak tahu cara menyikapi mual dan muntah yang dialaminya sehingga ibu beranggapan mual dan muntah adalah hal yang biasa dan tidak perlu penanganan khusus.

\section{Hubungan pengetahuan ibu dengan kejadian mual muntah}

Analisa bivariat yang dilakukan terhadap hubungan pengetahuan ibu dengan kejadian mual muntahpada kehamilan trimester pertama dapat diketahui bahwa dari 25 responden yang berpengetahuan rendah tentang dengan kejadian mual muntah pada kehamilan trimester pertama, hampir seluruhnya(76\%) responden yaitu 19 orang ibu mengalami mual muntah pada kehamilan trimester pertama sedangkan dari I5orang ibu yang berpengetahuan tinggi hampir seluruhnya (86,7\%) responden yaitu 13 orang ibu tidak mengalami mual muntah pada kehamilan trimester pertamanya. Pengetahuan adalah merupakan hasil "tahu" dan ini terjadi setelah orang melakukan penginderaan terhadap suatu objek tertentu. Penginderaan ini terjadi melalui panca indra manusia. Pengetahuan atau kognitif merupakan domain yang sangat penting bagi terbentuknya tindakan seseorang. Perilaku yang didasari oleh pengetahuan akan lebih langgeng daripada perilaku yang tidak didasari oleh pengetahuan (Nursalam, 20I4). Pengetahuan adalah suatu istilah yang dipergunakan untuk menuturkan apabila seseorang mengenal tentang sesuatu.Suatu hal yang menjadi pengetahuannya adalah selalu terdiri atas unsur yang mengetahui dan yang diketahui serta kesadaran mengenai hal yang ingin diketahui.Oleh karena itu pengetahuan selalu menuntut adanya subjek yang mempunyai kesadaran untuk mengetahui tentang sesuatu dan objek yang merupakan sesuatu yang dihadapi.Jadi bisa dikatakan pengetahun adalah hasil tahu manusia terhadap sesuatu, atau segala perbuatan manusia untuk memahami suatu objek tertentu (Surajiyo, 20I5). Hasil uji statistik terhadap hubungan pengetahuan ibu dengan kejadian mual muntah didapatkan $\mathrm{p}=0,000$, hasil ini menunjukkan adanya hubungan yang bermakna ( $p$ value $<0,05)$ antara pengetahuan ibu tentang cara mengatasi mual muntah dengan kejadian mual muntah pada kehamilan trimester pertama di Poskesdes Ampalu Bidan Helfiati, Amd.Keb tahun 2019. Hasil penelitian ini senada dengan penelitian yang dilakukan oleh Siti Zaerotun, dkk (2015) tentang hubungan karakteristik, paritas dan pengetahuan dengan upayamengatasi mual muntah pada kehamilan trimester I dengan hiperemesis gravidarumdi rumah sakit PKU Muhammadiyah Gubug Kabupaten Grobogan, dari hasil uji statistik dengan menggunakan korelasi rankspearman didapatkan nilai koefisien korelasi sebesar 0,399 dengan nilai $p$ sebesar 0,016 ( $p<0,05)$, hal ini menunjukkan terdapat hubungan yang bermakna antara pengetahuan dengan upaya mengatasi mual muntah ibu hamil trimester I. Dapat dianalisa bahwa pengetahuan sangat mempengaruhi seseorang dalam membuat keputusan. Dapat terlihat dari hasil penelitian ini, apabila responden berpengetahuan tinggi maka hampir seluruhnya ibu-ibu tidak mengalami mual dan muntah setiap hari dan sebaliknya apabila responden berpengetahuan rendah hampir seluruhnya mengalami mual dan muntah setiap hari. Hal ini mungkin karena melalui pengetahuan yang tinggi ibu akan lebih banyak mengetahui informasi dan mencari tahu mengenai mual muntah pada kehamilannya sehingga ibu tahu cara menanganinya sehingga ibu tidak mengalami mual dan muntah setiap hari.

\section{Hubungan sikap ibu dengan kejadian mual muntah}

Analisa bivariat yang dilakukan terhadap hubungan sikap ibu dengan kejadian mual muntah pada kehamilan trimester pertama dapat diketahui bahwa dari 17 responden yang bersikap negatif dalam mengatasi mual muntah pada kehamilan trimester pertama, hampir seluruhnya $(88,2 \%)$ responden yaitu 15 orang ibu 
Rika Armalini, Prasetyaningsih. 2020. Relationship Between Knowledge And Attitudes Of Pregnant Women And The Occurrence Of Vomiting In First Trimester Pregnancy In Poskesdes Ampalu Kota Pariaman Bidan Helfiati, Amd. Keb.

mengalami mual muntah pada kehamilan trimester pertama sedangkan dari 23 orang ibu yang bersikap positif sebagian besar $(73,9 \%)$ responden yaitu 17 orang ibu tidak mengalami mual muntah pada kehamilan trimester pertamanya. Sikap adalah keadaan mental dan saraf dari kesiapan yang diatur melalui pengalaman yang memberikan pengaruh dinamik atau terarah terhadap respon individu pada semua objek dan situasi yang berkaitan dengannya (Widayatun, 2014). Menurut Arikunto (2014) sikap merupakan reaksi atau respon yang masih tertutup dari seseorang terhadap suatu stimulus atau objek.Manifestasi sikap itu tidak dapat langsung dilihat, tetapi hanya dapat ditafsirkan terlebih dahulu dari perilaku yang tertutup. Sikap merupakan kesiapan untuk bereaksi terhadap objek di lingkungan tertentu sebagai suatu penghayatan terhadap objek. Hasil uji statistik terhadap hubungan sikap ibu dengan kejadian mual muntah didapatkan $p=0,000$, hasil ini menunjukkan adanya hubungan yang bermakna ( $P$ value $<0,05$ ) antara sikap ibu tentang cara mengatasi mual muntah dengan kejadian mual muntah pada kehamilan trimester pertama di Poskesdes Ampalu Bidan Helfiati, Amd.Keb tahun 2019. Hasil penelitian ini senada dengan penelitian yang dilakukan oleh Rima Fajar Anggraini, dkk (20ll) tentang hubungan pengetahuan dan sikap ibu hamil dengan kejadian mual muntah di BPS Ny. Widi Astutik, Amd.Keb. Hasil pengujian statistik diperoleh ada hubungan pengetahuan dan sikap ibu hamil dengan kejadian mual muntah, nilai korelasi 0,560.

\section{KESIMPULAN}

Sebagian besar responden berpengetahuan rendah dengan kejadian mual muntah pada kehamilan trimester pertama di Poskesdes Ampalu Bidan Helfiati, Amd.Keb tahun 2019; Kurang dari sebagian responden bersikap negatif dengan kejadian mual muntah pada kehamilan trimester pertama di Poskesdes Ampalu Bidan Helfiati, Amd.Keb tahun 2019; Sebagian besar responden mengalami mual dan muntah pada kehamilan trimester pertama di Poskesdes Ampalu Bidan Helfiati, Amd.Keb tahun 2019; Terdapat hubungan yang bermakna antara pengetahuan ibu dengan kejadian mual muntah dengan kejadian mual muntah pada kehamilan trimester pertama di Poskesdes Ampalu Bidan Helfiati, Amd.Keb tahun 2019; Terdapat hubungan yang bermakna antara sikapibu dengan kejadian mual muntah dengan kejadian mual muntah pada kehamilan trimester pertama di Poskesdes Ampalu Bidan Helfiati, Amd.Keb tahun 2019.

\section{UCAPAN TERIMA KASIH}

Puji syukur kehadirat Allah SWT, yang telah melimpahkan rahmat dan hidayah-Nya sehingga penulis dapat menyelesaikan Penelitian yang berjudul "Hubunggan Pengetahuan dan Sikap Ibu Hamil Dengan Kejadian Mual Muntah pada Kehamilan Trimester Pertamadi Poskesdes Ampalu Bidan Helfiati Amd.Keb Tahun 2019 "Untuk itu penulis penulis mengucapkan terima kasih kepada: Seluruh Dosen Dan Staf Akademi STIKes Piala Sakti Pariaman yang telah memberikan dukungan dalam menyelesaikan Penelitian ini. 8. Teristimewa kedua orang tua penulis beserta seluruh keluarga yang telah memberikan dorongan baik moral maupun material do'a restu serta harapan yang selalu menjadi semangat disetiap langkah penulis untuk mencapai cita-cita.

\section{REFERENSI}

I. Nuha Media WHO, 2013. Kejadian Tentang emesis gravidarum.

2. BKKBN. 20I3. Hasil SDKI Angka Kematian Ibu 2012.

http://www.bkkbn.go.id/ViewBerita.aspx?BeritalD $=900$ (sitasi 20 november 20I3).

3. Depkes, 2010. Program perencanaan dan komplikasi mempercepat penurunan AKI dan AKB. Jakarta

4. Janiwarti 2013. tingkat pengetahuan ibu hamil tentang mual muntah, salemba medika:jakarta

5. Rukiyah $\mathrm{Ai}$ Yeyeh, 2013. Asuhan Kebidanan 4 Patologi, jakarta 
6. Hutahaean \& Runiari, 2010. Penangaruh Kehamilan Terhadap Mual Muntah Dalam Keahamilan, Jakarta, ECG.

7. Natoatmodjo, S, 2012. Promosi Kesehatan Teori Dan Aplikasi, Jakarta :PT Rineka Cipta

8. Wawan, A 20ll. Teori dan Pengukuran Pengetahuan Sikap Dan Perilaku Manusia. Yogyakarta:

9. Wawan 2010. Manajemen Penelitian, Cetakan ketujuh, Rineka Cipta, Jakarta

10. Runiari, 2010. Pengaruh Mual Muntah dan Gangguan lain Selama Kehamilan, Manukberi, diaglossia

II. Arikunto, Suharsimi, 2010. Manajemen Penelitian, Rineka Cipta, Jakarta 